\title{
Metastatic breast cancer survival according to HER2 and Topo2a gene status
}

\author{
N. Todorović-Rakovića,*, Z. Nešković-Konstantinovićb and D. Nikolić-Vukosavljevića \\ ${ }^{a}$ Department of Experimental Oncology, Institute for Oncology and Radiology of Serbia, Belgrade, Serbia \\ ${ }^{\mathrm{b}}$ Department of Clinical Oncology, Institute for Oncology and Radiology of Serbia, Belgrade, Sebia
}

\begin{abstract}
The aim of this study was to determine the relationship between amplification of HER2 (Human epidermal growth factor receptor 2) and Topo2a (topoisomerase 2a) and their influence on prognosis in metastatic breast cancer (MBC) patients. Amplification of both HER2 and Topo2a genes was determined by chromogenic in situ hybridization (CISH) in primary tumor tissue of $71 \mathrm{MBC}$ patients. Starting point for follow-up was the time of diagnosis of metastatic disease.

Although there was significant correlation between HER2 amplification and Topo2a alterations, Topo2a amplification was not strictly related to HER2 amplification. Follow-up of patients showed that there was no difference in MBC survival between HER2-nonamplified and HER2-amplified patients for subgroup as whole, but there was significant difference in MBC survival between patients with and without Topo2a amplification. HER2 amplification showed prognostic value in subgroups of patients, as well as Topo2a. Combination of these two genes with different status (nonamplified, amplified, coamplified) indicated that they might have additive effect. Also, it has been shown that Topo2a-amplified cases have poorer survival than Topo2a-nonamplified, when treated with CMF therapy.

Topo2a amplification seems to be more promising biomarker of MBC survival, than HER2, and potential marker of resistance to CMF therapy.
\end{abstract}

Keywords: Metastatic breast cancer, CISH, HER2, Topo2a

\section{Introduction}

Metastatic breast cancer as a final stage of breast cancer, is a result of the biological expression of multiple genetic changes. Among these genetic alterations, gene amplification is the most frequent and represent important mechanism for oncogene overexpression in malignant tumor. For many years, a growth factor receptor gene HER2 was considered as target gene for amplification in chromosome 17 (amplicon) although, it is well known that HER2 is not the only gene that is amplified in the so called HER2 overexpression cluster [1]. It is possible that altered expression of these

*Corresponding author: Nataša Todorović-Raković, Department of Experimental Oncology, Institute for Oncology and Radiology of Serbia, Pasterova 14, 11000 Belgrade, Serbia. Tel.: +381 112067 213; Fax: +381 112685 300; E-mail: todorovicn@ncrc.ac.yu. coamplified genes might also have biological relevance and clinical significance in breast cancer.

Topo 2 a gene is located adjacent to the HER2 oncogene at the chromosome 17. Although amplified simultaneously HER2 and Topo2a are not always present in the same amplicon [2]. Topo2a is either amplified or deleted, with equal frequency, in almost $90 \%$ of HER2 amplified primary breast tumors [3], but the level of HER2 amplification does not predict for Topo2a amplification [4] and Topo2a expression is not strictly related to HER2 expression. Topo2a is DNA-modifying enzyme that can pass segment of DNA duplex through reversibile enzyme-mediated double-strand break [5]. Therapies that target Topo2a appear to act by binding to the enzyme-DNA complex and inducing lethal cellular damage, by the inhibition of the religation step during the transient DNA cleavage reaction. The status of Topo2a is further complicated by findings regarding its expression. Beside Topo2a amplification there are also 
cases of Topo 2 a gene deletions that render the tumors resistant to therapy [6]. Recent research showed that overexpression of HER2 and Topo2a are independent prognostic factors for anthracycline response and that overexpression of Topo2a could indicate a poor prognosis irrespective of the therapy applied [7]. Beside the studies directed to determine the predictive role of Topo2a as a target for anticancer therapies, there is a lack of studies regarding prognostic value of HER2 and Topo2a, especially in metastatic breast cancer (MBC) when risk evaluation is based on different parameters than for primary breast cancer [8]. In the context of metastatic disesase, it is important to say that HER2 and Topo2a expression remains fairly constant during chemotherapy and indeed during metastatic process [9].

\section{Material and methods}

71 metastatic breast cancer patients with known clinicopathological parameters (age, menopausal status, steroid receptor status, tumor size, nodal status, existence of distant metastasis and histologic type). were included in the study, initially diagnosed at different stages of the disease, Distribution of clinicopathological characteristics between breast cancer phenotypes (according to HER2 or Topo2a status) is presented in Table 2. (Results). At the time of primary diagnosis $69 \%$ of patients had positive lymph node status (N1 and $\mathrm{N} 2$ ) and 9\% had distant metastases. At the time of diagnosis of metastatic disease, $89 \%$ of patients had multiple metastases, mostly involved bone, liver and lung and the rest had single visceral or bone involvement. In metastatic setting $77 \%$ of patients received CMF (cyclophosphamide, methotrexate, 5fluorouracil) 47\% received FAC (5-fluorouracil, adriablastin, cyclophosphamide) and 51\% hormonal therapy (tamoxifen). Therapy was administered successively and in that line, no additional therapy was planned before evidence of treatment failure (progression of disease). Median follow-up period for the cohort at the time of analysis was 5 years. Tumors were chosen from prospectively collected tissue samples at the Institute for Oncology and Radiology of Serbia and processed at the same Institute. Histopathological classification was done on $\mathrm{HE}$ - stained slides according to standard histopathological practice. All of the tissues samples were fixed in neutral buffered formalin and embedded in paraffin. Serial sections of $4 \mu \mathrm{m}$ thicknesses on Superfrost/Plus microscope slides were obtained from representative tissue blocks, baked 4 hours on $60^{\circ} \mathrm{C}$ and processed according to the manufacturer's instructions.

\section{1. $\mathrm{CISH}$}

Tissue slides were deparaffinizied in xylene $(2 \times$ 10 minutes $)$ and washed in $100 \%$ ethanol $(3 \times 3$ minutes). When dry, slides were incubated 15 minutes at $96^{\circ} \mathrm{C}\left(92-100^{\circ} \mathrm{C}\right)$ in Spot-Light Tissue Heat Pretreatment Buffer (Zymed Inc. San Francisco, CA), cooled down for 20 minutes and washed in PBS $2 \times 3$ minutes. Tissue was covered with $100 \mu \mathrm{l}$ of Spot-Light Tissue Pretreatment Enzyme (Zymed Inc.) and incubated at $37^{\circ} \mathrm{C}$ for 10 minutes. After that, slides were washed in phosphate-buffered saline (PBS) and dehydrated in $70 \%, 85 \%, 95 \%, 2 \mathrm{x}$ in $100 \%$ ethanol for 2 minutes each. Slides were denaturated in denaturation buffer (containing formamide, $20 \mathrm{x}$ standard saline citrate SSC and ddH2O) at $78^{\circ} \mathrm{C}$ in water bath. Digoxigeninlabeled probe (Spot-Light HER-2 DNA probe, Zymed Inc.) was denaturated in the same way. The same refers to Spot-Light Topo2a DNA probe (Zymed Inc.). After dehydratation, $16 \mu \mathrm{l}$ probes was added on each slide, covered with coverslip and incubated overnight at $37^{\circ} \mathrm{C}$. After incubation, slides were washed in $0.5 \mathrm{x}$ standard saline citrate, 5 minutes at $78^{\circ} \mathrm{C}$ and treated with quenching solution (containing hydrogen peroxide and absolute methanol). After washing in PBS/Tween 20 for $3 \times 2$ minutes, Spot-Light CISH Detection Kit (Zymed Inc.) was used for chromogenic visualization.

Hybridization results were evaluated in $40 \mathrm{x}$ and 100x magnification field (Olympus BX51 microscope). From 1 to 5 gene copies per nucleus were defined as no amplification and more than 6 copies per nucleus (small or large gene copy cluster) in $>50 \%$ of tumor cells as amplification. Topo2a deletion is evident when the Topo2a gene copy number is less than in diploid state. Also, because most aneuploidy results fall within the gray area of 3 to 5 signals, setting the threshold of cut off signal points to a high of 6 or more (as in this study) eliminates the variability due to aneuploidy and makes the testing of polysomy chromosome 17 unnecessary.

\subsection{Statistical analysis}

Correlation between HER 2 and Topo2a gene status, was analyzed by the Chi-square test. $P$ value less than 0,05 were considered as statistically significant. The metastatic breast cancer survival curves were constructed according to the Kaplan-Meier method and compared with the log-rank test. 


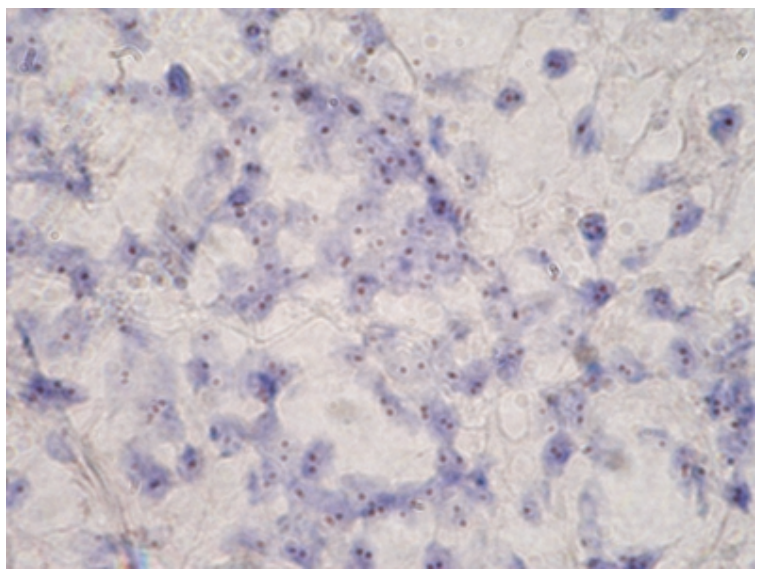

(a)



(b)

Fig. 1. CISH detection of HER2 nonamplified (1a) and amplified cases (1b).

\section{Results}

Examples of HER2 and Topo2a nonamplified, low anf high amplified cases by CISH are presented in Figs 1 and 2. There was a significant correlation between HER2 amplification and Topo2a gene alterations (Table 1). Patients with deletion of Topo2a because of the small number of cases $(n=7)$ were not included in follow-up analyses. When performing CISH, 3-5 copies (of any gene) per nucleus is considered as possible aneuploidy and in all CISH studies aneuploidy is not treated as a cause of significant protein overexpression. In such cases it is accepted that aneuploidy is treated same as normal, diploid state i.e. 2 copies or as no amplification of certain gene. Neither HER2 or Topo2a amplification showed correlation with available clinicopathological parameters (Table 2).

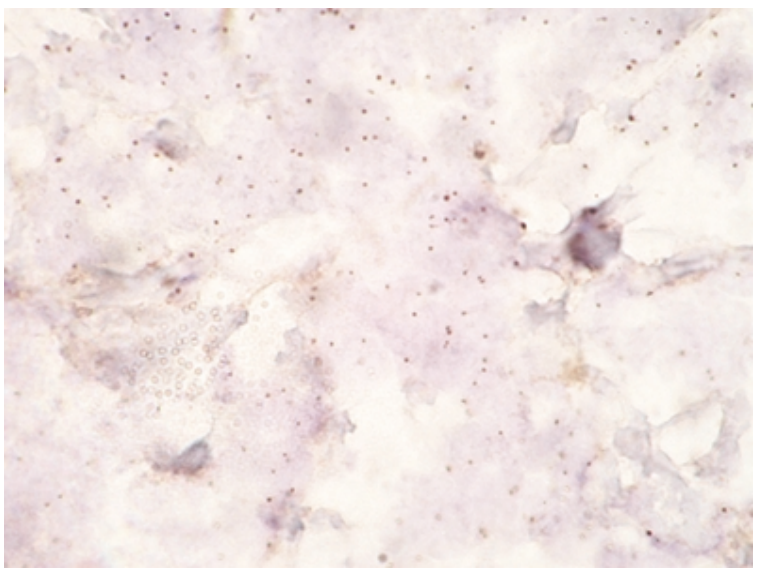

(a)

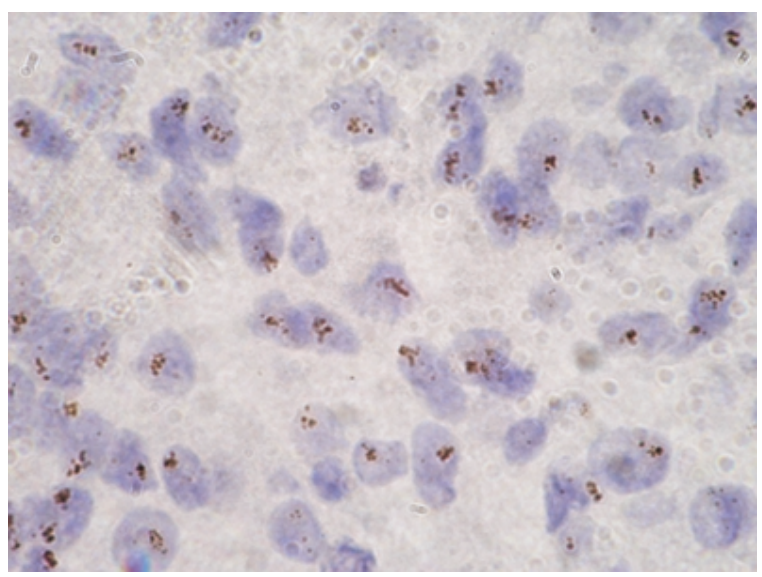

(b)

Fig. 2. CISH detection of Topo2a nonamplified (2a) and amplified cases (2b).

Table 1

Correlation between Topo2a gene alterations (amplification and deletion) and HER2 amplification (Chi-square test $p=0.04$ )

\begin{tabular}{lrrrrr}
\hline & \multicolumn{2}{c}{ HER2 } & nonamplified & & \multicolumn{2}{c}{ HER2 amplified } \\
\cline { 2 - 3 } \cline { 5 - 6 } & $\mathrm{n}$ & $\%$ & & $\mathrm{n}$ & $\%$ \\
\hline Topo2a nonamplified & 24 & 71 & & 15 & 40 \\
Topo2a amplified & 8 & 23 & & 17 & 46 \\
Topo2a deleted & 2 & 6 & & 5 & 14 \\
\hline
\end{tabular}

Time of diagnosis of metastatic disease (whether patients are initially diagnosed as metastatic or not) is taken as starting point for metastatic breast cancer survival curves. In subgroup as whole, independent of therapy applied, there was no statistically significant difference in metastatic breast cancer survival between HER2nonamplified cases and HER2-amplified cases (Table 3. Figure 3a). In contrast, there was statistically significant difference in MBC survival between Topo2a- 
Table 2

Correlation between HER2/Topo2a status and available clinico-pathological parameters (Chi-square test). Nonavaliable data for all variables are not indicated in the table

\begin{tabular}{|c|c|c|c|c|c|c|}
\hline $\begin{array}{l}\text { Clinico-pathological } \\
\text { parameters }\end{array}$ & $\begin{array}{c}\text { HER2- } \\
\mathrm{n}\end{array}$ & $\begin{array}{c}\text { HER2+ } \\
\text { n }\end{array}$ & $\mathrm{p}$ & $\begin{array}{c}\text { Topo2a- } \\
\mathrm{n}\end{array}$ & $\begin{array}{c}\text { Topo2a+ } \\
\mathrm{n}\end{array}$ & $\mathrm{p}$ \\
\hline \multicolumn{7}{|l|}{ Age } \\
\hline$</=50$ & 13 & 17 & nss & 15 & 12 & nss \\
\hline$>50$ & 20 & 20 & & 13 & 13 & \\
\hline \multicolumn{7}{|l|}{ Menopausal status } \\
\hline pre & 17 & 18 & nss & 20 & 10 & nss \\
\hline post & 17 & 18 & & 19 & 14 & \\
\hline \multicolumn{7}{|l|}{ Estrogen receptor } \\
\hline ER - & 10 & 21 & nss & 14 & 14 & nss \\
\hline ER+ & 20 & 15 & & 22 & 9 & \\
\hline \multicolumn{7}{|l|}{ Progesteron receptor } \\
\hline PR- & 13 & 22 & nss & 19 & 11 & nss \\
\hline \multicolumn{7}{|l|}{ Tumor size } \\
\hline $\mathrm{T} 1$ & 6 & 8 & & 4 & 6 & \\
\hline $\mathrm{T} 2$ & 18 & 18 & nss & 22 & 13 & nss \\
\hline T3 & 1 & 5 & & 4 & 3 & \\
\hline T4 & 6 & 7 & & 7 & 3 & \\
\hline \multicolumn{7}{|l|}{ Nodal status } \\
\hline $\mathrm{N}-$ & 6 & 7 & nss & 6 & 5 & nss \\
\hline $\mathrm{N}+$ & 24 & 28 & & 30 & 19 & \\
\hline \multicolumn{7}{|l|}{ Distance metastases } \\
\hline $\mathrm{M}-$ & 30 & 31 & nss & 36 & 19 & nss \\
\hline M+ & 2 & 6 & & 2 & 5 & \\
\hline \multicolumn{7}{|l|}{ Histological type } \\
\hline IDC & 19 & 26 & nss & 21 & 20 & nss \\
\hline ILC & 9 & 6 & & 9 & 4 & \\
\hline ostalo & 3 & 0 & & 3 & 0 & \\
\hline \multicolumn{7}{|l|}{ Stage } \\
\hline I & 5 & 4 & & 4 & 3 & \\
\hline II & 20 & 19 & nss & 21 & 15 & nss \\
\hline III & 7 & 6 & & 10 & 2 & \\
\hline IV & 2 & 6 & & 2 & 5 & \\
\hline
\end{tabular}

Table 3

Mortality, median survival time and $\mathrm{p}$ values for comparison of subgroups of patients according to their HER2 status and Topo2a status (nonamplified / amplified)

\begin{tabular}{|c|c|c|c|c|c|}
\hline \multirow[t]{2}{*}{ Gene status } & \multirow[t]{2}{*}{$\mathrm{n}$} & \multicolumn{2}{|c|}{ Mortality } & \multirow{2}{*}{$\begin{array}{l}\text { Median survival } \\
\text { time (months) }\end{array}$} & \multirow{2}{*}{$\begin{array}{c}\text { P value } \\
\text { (Log rank) }\end{array}$} \\
\hline & & $\mathrm{n}$ & $\%$ & & \\
\hline HER2 - & 60 & 28 & 47 & 44 & \\
\hline HER2 + & 40 & 20 & 50 & 29 & 0.1 \\
\hline Topo2a - & 37 & 15 & 40 & 54 & \\
\hline Topo2a + & 25 & 18 & 72 & 24 & 0.006 \\
\hline
\end{tabular}

amplified cases and Topo2a-nonamplified, (Fig. 3b). Yet, when patients were stratified according to their clinicopathological characteristics, there was statistically significant difference in survival in different subgroups according to their HER2 status and Topo2a status (Tables 4 and 5). Further, combination of HER2 and Topo2a gene status showed that there is a statistically significant difference in survival of patients, depending of different combinations of these two genes (Table 6) i.e. different breast cancer phenotypes. According to

\section{Table 4}

Mortality, median survival time and $\mathrm{p}$ values in subgroups of patients according to HER2 gene status (with statistically significant difference): postmenopausal patients, patients with positive nodal status and patients older than 50 years

\begin{tabular}{lccccc}
\hline HER2 subgroups & $\mathrm{n}$ & \multicolumn{2}{c}{ Mortality } & $\begin{array}{c}\text { Median survival } \\
\text { time }\end{array}$ & $\begin{array}{c}\text { P value } \\
\text { (Log rank) }\end{array}$ \\
\cline { 3 - 4 } & & $\mathrm{n}$ & $\%$ & & \\
postmenopausal & & & & & \\
HER2 - & 32 & 12 & 37 & 17 & 0.004 \\
HER2 + & 20 & 14 & 70 & & \\
$\mathrm{~N}+$ & & & & & \\
HER2 - & 48 & 21 & 44 & 44 & 0.04 \\
HER2 + & 31 & 18 & 58 & 19 & \\
$>$ 50 years & & & & & \\
HER2 - & 26 & 12 & 46 & 44 & 0.02 \\
HER2 + & 19 & 13 & 68 & 17 & \\
\hline
\end{tabular}

these results, it is clear that there is additive effect between these two genes and that their coamplification leads to extremly poor prognosis with median survival time of 17 months.

Interaction between HER2 and Topo2a gene status 


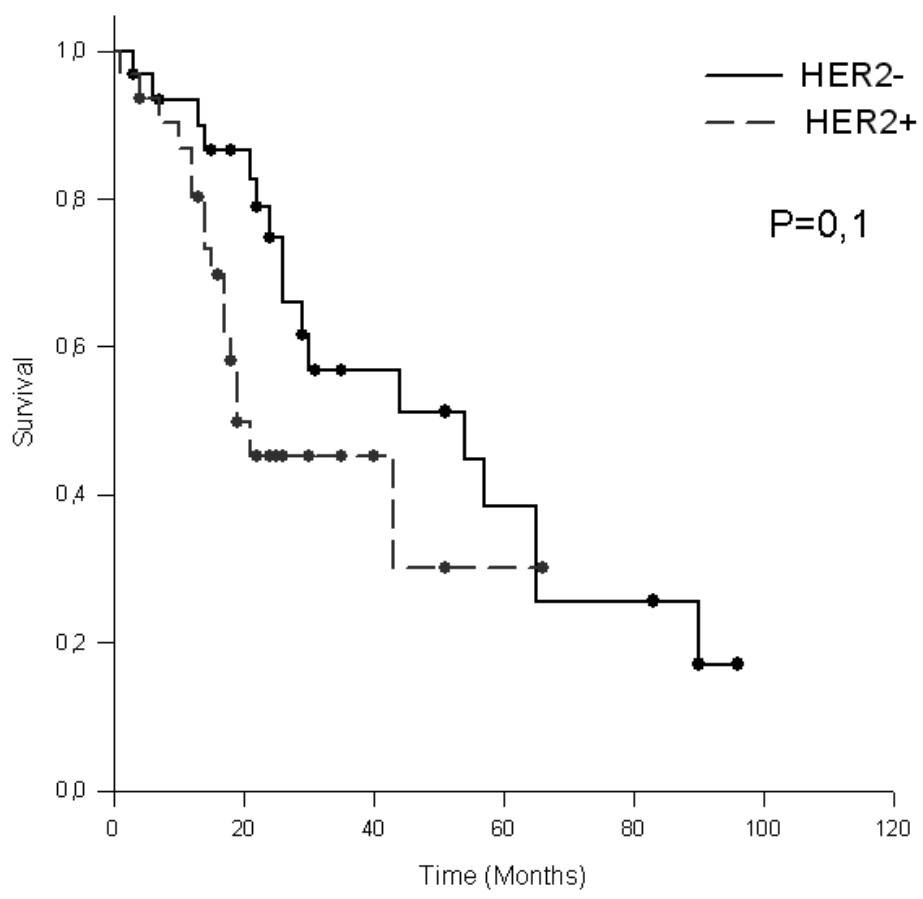

(a)

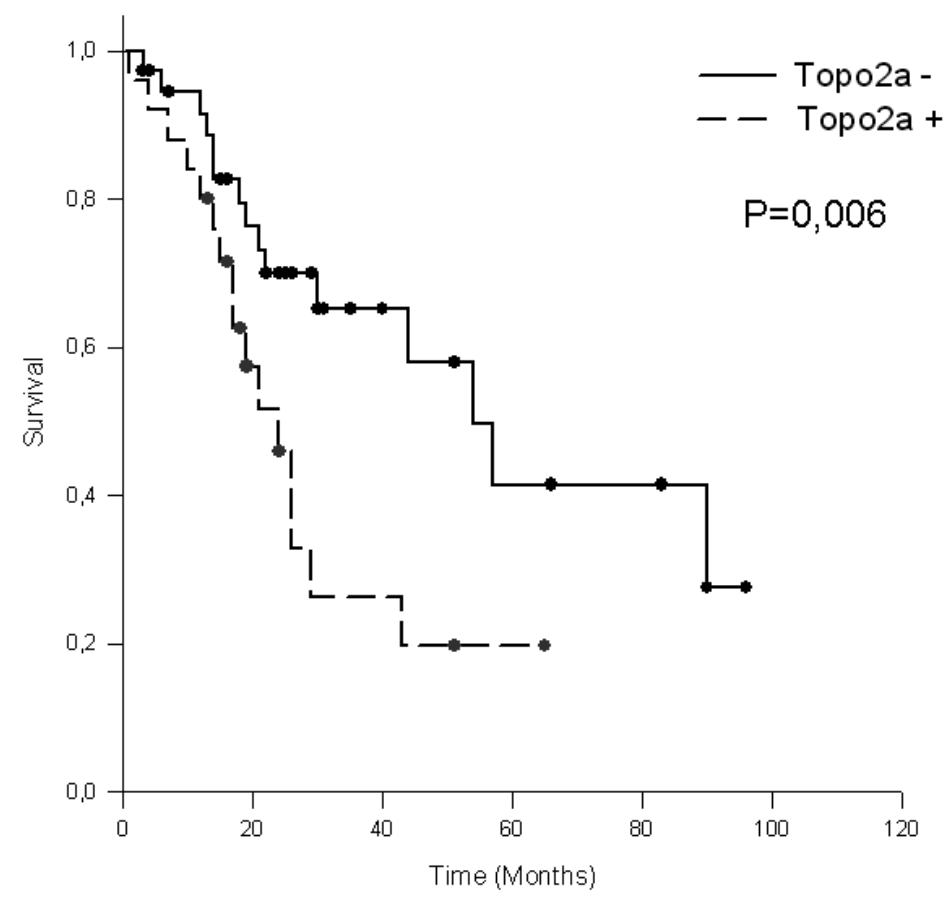

(b)

Fig. 3. Metastatic breast cancer survival curves according to HER2 (HER2 nonamplified versus HER2 amplified) (3a) ( $p=0.1)$ and Topo2a status (Topo2a nonamplified versus Topo2a amplified) ( $3 \mathrm{~b})(p=0.006)$. P values are determined by log-rank test. 
Table 5

Mortality, median survival time and $\mathrm{p}$ values in subgroups of patients according to Topo2a gene status (with statistically significant difference): patients older than 50 years, patients with positive nodal status, patients without distant metastasis at time of diagnosis, patients with stage I and II and patients with invasive ductal carcinoma (IDC)

\begin{tabular}{lrrrcc}
\hline $\begin{array}{l}\text { Topo2a } \\
\text { subgroups }\end{array}$ & $\mathrm{n}$ & \multicolumn{2}{c}{$\begin{array}{c}\text { Mortality } \\
\mathrm{n}\end{array}$} & $\begin{array}{c}\text { Median survival } \\
\text { time }\end{array}$ & $\begin{array}{c}\text { P value } \\
\text { (Log rank) }\end{array}$ \\
\hline $\begin{array}{l}\text { 50 years } \\
\text { Topo2a }-\end{array}$ & 15 & 7 & 47 & 54 & 0.04 \\
Topo2a + & 12 & 8 & 67 & 15 & \\
$\mathrm{~N}+$ & & & & & \\
Topo2a - & 29 & 12 & 41 & 59 & 0.02 \\
Topo2a + & 19 & 13 & 68 & 32 & \\
$\mathrm{M}-$ & & & & & \\
Topo2a - & 35 & 14 & 40 & 57 & 0.008 \\
Topo2a + & 19 & 14 & 73 & 24 & \\
stageI+II & & & & & \\
Topo2a - & 24 & 9 & 37 & 57 & 0.003 \\
Topo2a + & 18 & 13 & 72 & 21 & \\
IDC & & & & & \\
Topo2a - & 24 & 8 & 33 & 57 & 0.02 \\
Topo2a + & 23 & 16 & 69 & 21 & \\
\hline
\end{tabular}

Table 6

Mortality, median survival time and $\mathrm{p}$ values in subgroups of patients according to combined HER2 and Topo2a gene status i.e. different breast cancer phenotypes

\begin{tabular}{lrrrccc}
\hline Gene status & $\mathrm{n}$ & \multicolumn{3}{c}{ Mortality } & $\begin{array}{c}\text { Median survival } \\
\text { time }\end{array}$ & $\begin{array}{c}\text { P value } \\
\text { (Log rank) }\end{array}$ \\
\cline { 2 - 5 } & & $\mathrm{n}$ & $\%$ & & \\
HER2 - Topo2a - & 23 & 11 & 48 & 54 & \\
HER2 + Topo2a - & 14 & 4 & 29 & $/$ & 0.7 \\
HER2 - Topo2a - & 23 & 11 & 48 & 54 & \\
HER2 - Topo2a + & 8 & 6 & 75 & 29 & 0.9 \\
HER2 + Topo2a + & 17 & 12 & 71 & 17 & \\
HER2 + Topo2a - & 14 & 4 & 29 & $/$ & 0.01 \\
HER2 + Topo2a + & 17 & 12 & 71 & 17 & \\
HER2 - Topo2a + & 8 & 6 & 75 & 29 & 0.01 \\
HER2 - Topo2a + & 8 & 6 & 75 & 29 & \\
HER2 + Topo2a - & 14 & 4 & 29 & $/$ & 0.5 \\
HER2 - Topo2a - & 23 & 11 & 48 & 54 & \\
HER2 + Topo2a + & 17 & 12 & 71 & 17 & 0.004 \\
\hline
\end{tabular}

Table 7

Mortality, median survival time and $\mathrm{p}$ values in subgroups of patients according to HER2 and Topo2a gene status, treated with CMF.

\begin{tabular}{lrrrccc}
\hline CMF & $\mathrm{n}$ & \multicolumn{2}{c}{ Mortality } & $\begin{array}{c}\text { Median survival } \\
\text { time }\end{array}$ & $\begin{array}{c}\text { P value } \\
\text { (Log rank) }\end{array}$ \\
\cline { 3 - 4 } & & \multicolumn{1}{c}{$\mathrm{n}$} & $\%$ & 45 & \\
HER2 - & 29 & 13 & 45 & 44 & 0.4 \\
HER2 + & 26 & 12 & 46 & 29 & \\
Topo2a - & 23 & 9 & 39 & 54 & 0.01 \\
Topo2a + & 12 & 9 & 75 & 17 & \\
\hline
\end{tabular}

and treatment effect is presented in Tables 7, 8 and 9. and Figs 4 and 5. There was no statistically significant difference in patient's outcome between HER2nonamplified and HER2-amplified subgroups neither treated with CMF, FAC or tamoxifen (Figs 4a, 4b and 4c) but there was statistically significant difference
Table 8

Mortality, median survival time and $\mathrm{p}$ values in subgroups of patients according to HER2 and Topo2a gene status, treated with FAC

\begin{tabular}{lccccc}
\hline FAC & $\mathrm{n}$ & \multicolumn{2}{c}{ Mortality } & $\begin{array}{c}\text { Median survival } \\
\text { time }\end{array}$ & $\begin{array}{c}\text { P value } \\
\text { (Log rank) }\end{array}$ \\
\cline { 3 - 4 } & & $\mathrm{n}$ & $\%$ & & \\
HER2 - & 18 & 8 & 44 & 57 & 0.3 \\
HER2 + & 12 & 5 & 42 & $/$ & \\
Topo2a - & 14 & 4 & 28 & 57 & 0.4 \\
Topo2a + & 11 & 7 & 64 & 29 & \\
\hline
\end{tabular}

Table 9

Mortality, median survival time and p values in subgroups of patients according to HER2 and Topo2a gene status, treated with FAC

\begin{tabular}{lrrrccc}
\hline TAM & $\mathrm{n}$ & \multicolumn{2}{c}{ Mortality } & Median survival & $\begin{array}{c}\text { P value } \\
\text { (Log rank) }\end{array}$ \\
\cline { 3 - 4 } & & \multicolumn{1}{c}{$\mathrm{n}$} & $\%$ & & time & (Lonn \\
HER2 - & 23 & 14 & 61 & 42 & 0.4 \\
HER2 + & 15 & 9 & 60 & 21 & \\
Topo2a - & 11 & 6 & 54 & 44 & 0.3 \\
Topo2a + & 12 & 11 & 50 & 24 & \\
\hline
\end{tabular}

between Topo2a-nonamplified and Topo2a-amplified subgroups treated with CMF (Figs 5a, 5b and 5c).

\section{Discussion}

At present time, there is no biological marker established in routine practice for follow up of MBC patients survival or to assess clinical benefit from chemotherapy. Although it is well known that metastatic breast cancer is uncurable disease with median survival time of 2-4 years, efforts should be made to help in defining risk groups even in this final stage. Better subgrouping of patients could improve treatment and prolonge patients life. Progression of breast cancer to the final metastatic stage is based mostly on proliferation of malignant cells that succeed to survive adjuvant treatment because of features that provide them selective advantages. However, there is no defined biomarker related to the progression to and through metastatic breast cancer. HER2 and Topo2a are both related to proliferation in a different ways and amplification of these genes could only lead to increased proliferation.

Since the first study related to prognostic value of HER2 in breast cancer [10] that indicated that tumors with HER2 amplification tend to be more agressive than those without it, there were efforts through many clinical studies to confirm this finding. However, the clinical significance of this "the most popular" oncogene in breast cancer is still contraversial. This could be consequence of coamplification and increased expression of other genes contributing to certain features of breast cancer, more than expected and even more than HER2 itself. 


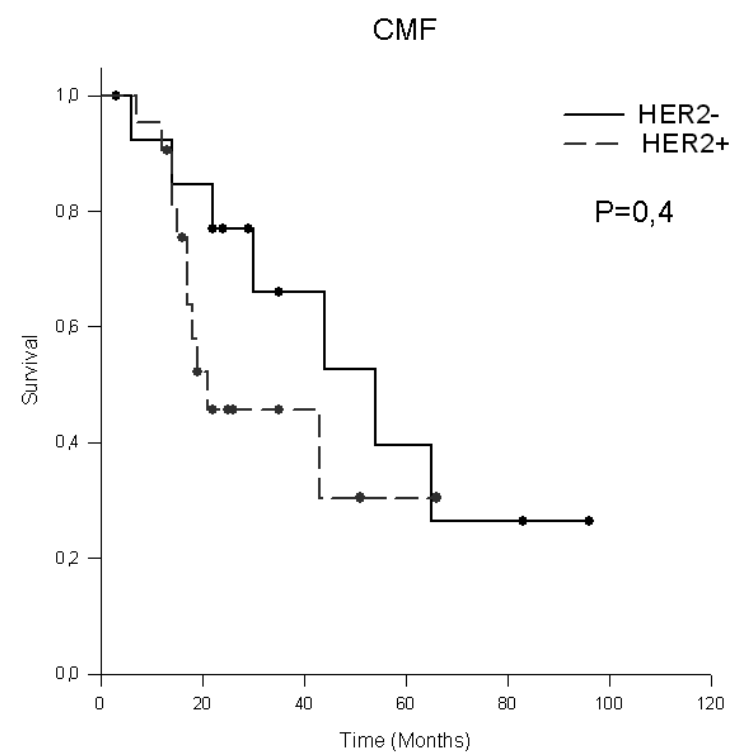

(a)
FAC

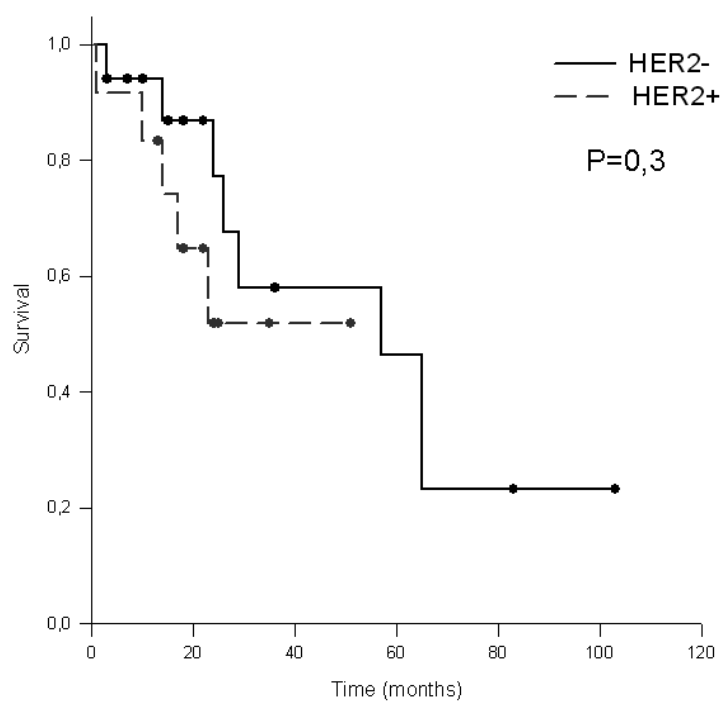

(b)

TAM

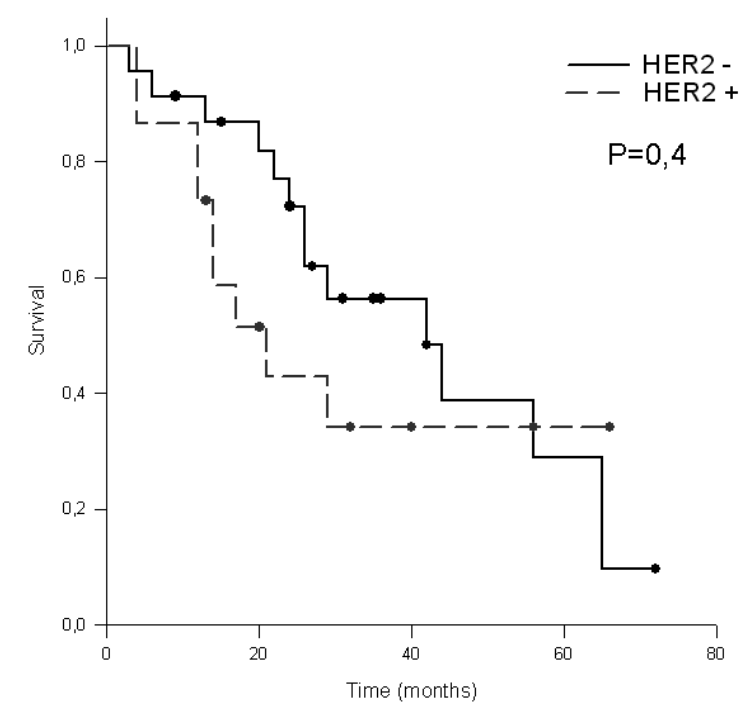

(c)

Fig. 4. Metastatic breast cancer survival curves according to HER2 status for patients that received CMF (4a), anthracycline (4b) or hormonal therapy $(4 \mathrm{c})$.

In our study, neither HER2 or Topo2a amplification has shown correlation with available clinicopathological parameters such as age, menopausal status, steroid receptor status (estrogen and progesteron receptors), tumor size, nodal status, distant metastases, histologic type and stage at time of diagnosis (Table 2). These results indicate that they should be considered as in- dependent parameters of prognosis in MBC. The correlation of Topo2a expression with other known prognostic parameters has been inconsistent $[11,12]$ Indeed, Topo2a is accepted as strictly proliferation marker in breast cancer, mostly because of its role and expression in proliferating cells [13]. However, it was shown that in transformed cells, Topo2a expression is higher and 
CMF

FAC

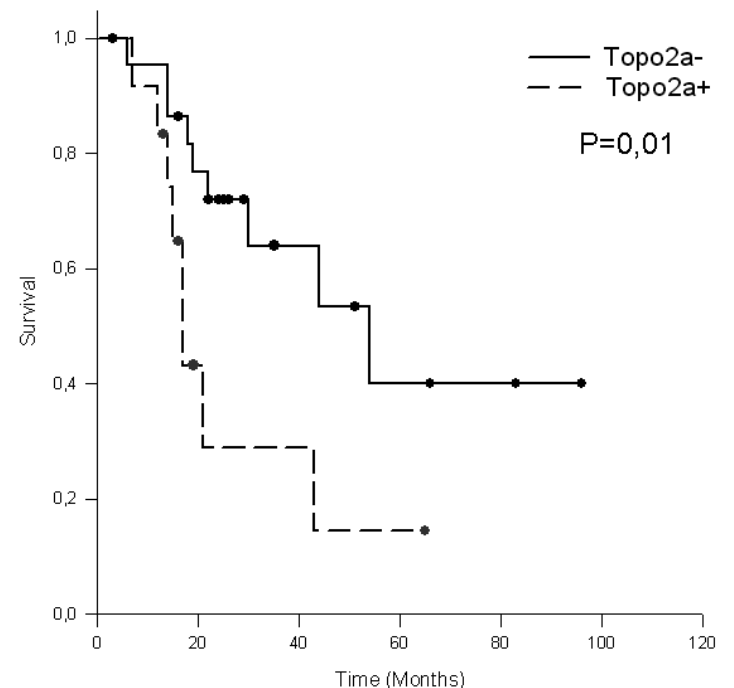

(a)

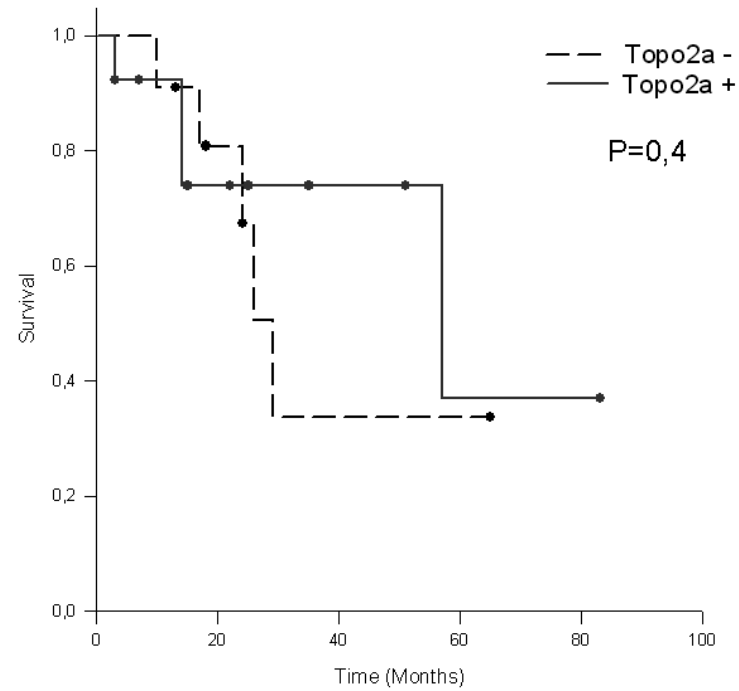

(b)

TAM

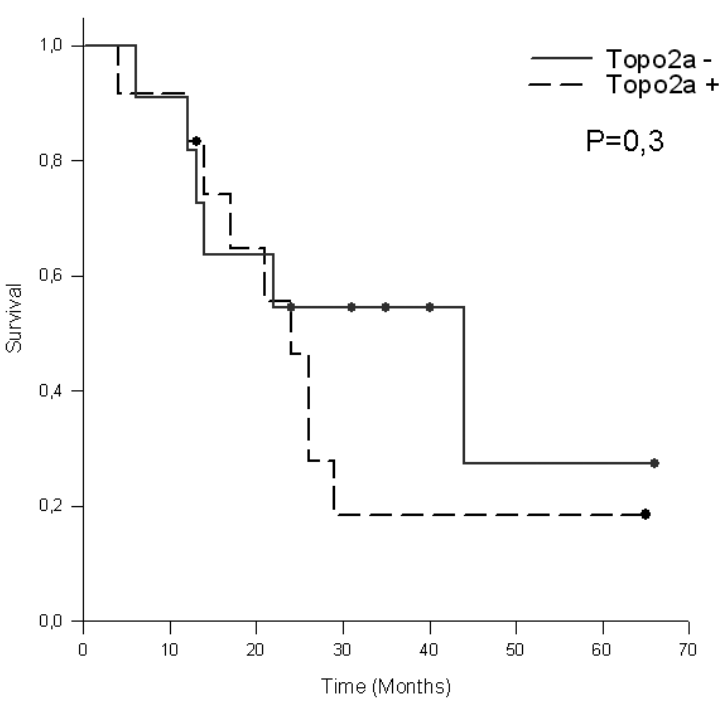

(c)

Fig. 5. Metastatic breast cancer survival curves according to HER2 status for patients that received CMF (5a), anthracycline (5b) or hormonal therapy $(5 c)$.

less dependent on the proliferative state of the cell.

In our study, unexpectedly Topo2a seems to be a better prognostic indicator in metastatic breast cancer than HER2, although there was significant correlation between alterations of these two genes (Table 1). There was no difference in MBC survival between patients with HER2 amplification and patients without HER2 amplification. but patients with Topo2a amplification had poorer prognosis in comparison with patients without Topo2a amplification. This finding reffers to whole subgroup of patients tested for Topo2a status in contrast to HER2 amplification (Table 3), independent of therapy applied, as well as in different subgroups (Table 5). HER2 amplification seems to have only limited prog- 
nostic value in different subgroups of patients (Table 4) but not in unselected group. However coamplification of these two genes seems to have additive effect on patients survival, because patients with coamplification had poorer survival than patients with single gene amplification (Table 6) and the difference in median survival time between these two groups of patients was extreme (17 vs. 54 months). For pateints with metastatic breast cancer this could be of the main importance.

Prognostic value that Topo2a amplification showed in unselected (by treatment) patients cohort, could be a consequence of its different predictive value in relation to different kinds of therapy in metastatic setting. The mechanisms of cytotoxic drug action are complex and involve several intracellular pathways. In that context, we tested interaction between HER2 and Topo2a status and treatment effect. Topo2a amplification seems to have predictive value related to $\mathrm{CMF}$ therapy. There was no statistically significant difference in clinical outcome of patients regarding their HER2 and Topo2a status, in relation to anthracyclinebased therapy (FAC) that is considered as targeted i.e. topo2a-inhibitor, neither in relation to hormonal therapy (tamoxifen). This is in agreement with recent immunohistochemical study comparing CMF and anthracycline-based therapy in adjuvant setting [14]. However, in this context it is important to say that increase in Topo2a expression is associated with sensitivity to anthracycline-based therapy presumably due to increased target. Although Topo2a expression is related to proliferation, it is not just a proliferation marker, moreover it has important role in central cellular processes such as replication and transcription [15] and could be involved in the mechanism behind clinical response to different kinds of chemotherapy Several studies in metastatic or locally advanced breast cancer patients have suggested a consistent relationship between Topo2a gene over-expression/amplification and benefit from anthracycline-based chemotherapy $[16,17]$. Also, Topo 2 a could be involved in a different ways in the mechanism behind clinical response to different kinds of chemotherapy. In vitro studies [18] showed that some cell lines selected for resistance to alkylators such as cyclophosphamide (as part of CMF therapy) have elevated levels od Topo2a. It has been suggested that Topo2a that is involved in DNA repair (through modulation of chromatin structure) has its role in multifactorial cellular response, perhaps as a part of a multienzyme complex important in repair of DNA damage. So, its importance is not restricted only to response to targeted topo2a-inhibitor therapy, especially in the context of new findings that does not support greater significance of Topo2a (and HER2) for this kind of treatment [19]. In this context, our results indicated no significance neither of HER2 or Topo2a amplification for response to anthracycline-based therapy (FAC) but strongly indicate the role of Topo2a amplification in a resistance to $\mathrm{CMF}$.

Prediction of the response to the CMF is controversial. HER2 has been first studied extensively as possible predictive marker for a variety of chemotherapy regimens. Some reports showed that response to anthracycline and CMF is independent of HER2 status [20-22] and the others suggested that CMF is effective only in HER2-negative [23] or only in HER2positive tumors [24]. There are evidence that HER2 might not be involved in chemosensitivity or resistance at all. The role of HER2 overexpression in chemosensitivity of cancer cells could be indirect and perhaps rests on the association of HER2 with other factors involved in the drug response (tumor grade, high proliferation, ER negativity or Topo2a expression) [25]. Normal human mammmary epithelial cells designed to overexpress HER2 by transfection with HER2 cDNA, showed no difference in chemosensitivity to the panel of chemotherapeutic agents (doxorubicin, 5-fluorouracil, paclitaxel, methotrexate and other) in the presence or absence of HER2 overexpression [26]. The controversial results of the avaliable retrospective studies and the opposite results of the current work on CMF do not support the routine use of HER2 status in everyday practice for treatment decision making. Topo2a is biologically most relevant gene located in the HER2 amplicon, providing the tumor cells growth stimulus that allows rapid proliferation of any surviving cells following treatment with cytotoxic drugs. In conclusion, according to our results Topo2a amplification seems to be important parameter for follow up of metastatic breast cancer patients, independent of HER2 status. Prognostic value of Topo2a could be result of corresponding interaction between Topo2a status and CMF treatment that couldnt reverse negative impact of Topo2a amplification. Its predictive potential and relation with HER2 gene status should be further reevaluated.

\section{Acknowledgment}

This work was supported by Grant No. 145018 "Molecular biomarkers of growth, invasiveness and metastasis in breast cancer: clinical and biological aspects" from the Ministry of Science and Environment Protection of Republic of Serbia. 


\section{References}

[1] P. Kauranemi, M. Barlund, O. Monni and A. Kallionemi, New amplified and highly expressed genes discovered in the ERBB2 amplicon in breast cancer by cDNA microarrays, Cancer Research 61 (2001), 8235-8240.

[2] T.A. Jarvinen, M. Tanner, M. Barlund, A. Borg and J. Isola, Characterization of topoisomerase II alpha gene amplification and deletion in breast cancer, Genes Chromosomes Cancer 26 (1999), 142-150.

[3] T.A. Jarvinen, M. Tanner, V. Rancancen et al., Amplification and deletion of topoisomerase2a gene are common in ErbB2 amplified breast cancer and alter sensitivuty to doxorubicin, American Journal of Pathology 156 (2000), 839-847.

[4] V. Durbecq, C. Desmed, M. Paesmans, F. Cardoso, A. Di Leo, M. Mano et al., Correlation between topoisomerase-IIalpha gene amplification and protein expression in HER-2 amplified breast cancer, Int J Oncol 5 (2004), 1473-1479.

[5] J.C. Wang, DNA topoisomerases, Аnnu Rev Biochem 65 (1996), 635-692.

[6] A. Di leo and J. Isola, Topoisomerase II alpha as a marker predicting the efficacy of anthracyclines in breast cancer: are we at the end of the beginning? Clinical Breast Cancer 4 (2003), 179-186.

[7] P. Fritz, C.M. Carbera, J. Dippon, A. Gerteis, W.E. Simon Waultzky et al., C-erbB2 and topoisomerase2a protein expressio independently predict poor survival in primary human breast cancer: a retrospective study, Breast Cancer Reserach 7 (2005), R374-R384.

[8] C. Bernard-Marty, F. Cardoso and M. Piccart, Facts and controversies in systemic treatment of breast cancer, The Oncologiest 9 (2004), 617-632.

[9] A. Vincent-Salomon, M. Jouve, P. Genin, P. Freneaux, B. Sigal-Zafrany, M. Caly et al., HER2 status in patients with breast carcinoma is not modified selectively by preoperative chemotherapy and is stable during the metastatic process, Cancer 94 (2002), 2169-2173.

[10] D.J. Slamon, G.M. Clark, G.C. Chamness, A. Ulrich and W.L. McGuire, Human breast cancer: correlation of relapse and survival with amplification of the HER-2 oncogene, Science 235 (1987), 177-181.

[11] T.A. Jarvinen, J. Kononen, M. Pelto-Huikko and J. Isola, Expression of topoisomerase 2alpha is associated with rapid cell proliferation, aneuploidy and c-erbB2 expression in breast cancer, Am J Pathol 148 (1996), 2073-2082.

[12] L. Depowski, S.L. Rosenthal, T.M. Brien, S. Stylis, R.L. Johnson and J.S. Ross, Topoisomerase 2 alpha expression in breast cancer: correaltion with clinical variables, Mod Pathol 13 (2000), 542-547.

[13] H. Turley, M. Comley, S. Houlbrook, N. Nozaki, A. Kikuchi, I.D. Hickson et al., The distribution and expression of the two isofdorms of DNA topoisomerase II in normal and neoplastic human tissues, British Journal of Cancer 75 (1997), 1340 1346.

[14] M. Collozza, A. Sidoni, A.M. Mosconi, A. Cavaliere, G. Bisagni, S. Gori et al., HER2 overexpression as pre- dictive marker in a randomized trial comparing adjuvant cyclophosphamide/methotrexate/5-fluorouracil with epirubicin in patients with stage I/II breast cancer: long-term results, Clin Breast Cancer 6 (2005), 253-259.

[15] J.J. Champoux, DNA topoisomerases: Structures, function and mechanism, Annu Rev Biochem 70 (2001), 369-413.

[16] F. Cardoso, V. Durbecq, D. Larsimont, M. Paesmans, J.Y. Leroy, G. Rouas et al., Correlation between complete response to anthracycline-based chemotherapy and topoisomearse 2alpha gene amplification and protein overexpression in locally advanced/metastatic breast cancer, International Journal of Oncology 24 (2004), 201-209.

[17] M. Marti-Richard, M. Munoz, J. Albanell, L. Colomo, M. Beller, M.J. Rey et al., Serial topoisomerase II expression in primary breast cancer and response to neoadjuvant anthracycline-based chemotherapy, Oncology 66 (2004), 388394.

[18] L.N. Harris, L. Yang, V. Liotcheva, S. Pauli, J.D. Iglehart, O.M. Colvin et al., Induction of Topoisomerase II activity after ErbB2 activation is associated with a differential response to breast cancer chemotherapy, Clinical Cancer Research 7 (2002), 1497-1504.

[19] F. Manna Edel, L.C. Teixeira and M. Alvarenga, Association between immunohistochemical expression of topoisomerase IIalpha, HER 2 and hormone receptors and response to primary chemotherapy in breast cancer, Tumori 92 (2006), 222-229.

[20] S. Paik. J. Bryant, E. Tan-Chiu, G. Yothers, C. Park, D.L. Wickerham et al., HER2 and choice of adjuvant chemotherapy for invasive breast cancer: National Surgical Adjuvant Breast and Bowel Project Protocol B-15, Journal of National Cancer Institute 92 (2000), 1991-1998.

[21] D.W. Miles, W.H. Harris, C.E. Gillett et al., Effect of cerbB2 and estrogen receptor status on survival of women with primary breast cancer treated with adjuvant cyclophosphamide/methotrexate/fluorouracil, Interantional Journal of Cancer 84 (1999), 354-359.

[22] S. Menard, P. Valagussa, S. Pilatti, L. Gianni, E. Biganzoli, P. Borachi et al., Response to cyclophosphamide, mehotrexate and fluorouracil in lymph node-positive breast cancer according to HER2 overexpression and other tumor biologic variables, Journal of Clinical Oncology 19 (2001), 329-335.

[23] B.A. Gusterson, R.D. Gelber, A. Goldhirsch et al., Prognostic importance of c-erb B2 expression in breast cancer, Journal of Clinical Oncology 10 (1992), 1049-1056.

[24] J.G.M. Klijn, E.M.J.J. Bern and J.A. Fockens, Prognostic factrors and response to therapy in breast cancer, Cancer Surv $\mathbf{1 8}$ (1993), 165-198.

[25] P. Rudolph, H. Olsson, G. Bonatz et al., Correlation between p53, c-erbB2 and topoisomerase 2alpha expression:DNA ploidy, hormonal receptor status and proliferation in 356 nodenegative breast carcinomas, Prognostic implications, J Pathol 187 (1999), 207-217.

[26] M.S. Orr, P.M. O Connor and K.W. Kohn, Effects of c-erbB2 overexpression on the drug sensitivities of nornmal human mammary epithelial cells, J Natl Cancer Inst 92 (2000), 987 994. 


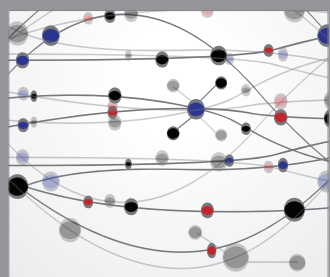

The Scientific World Journal
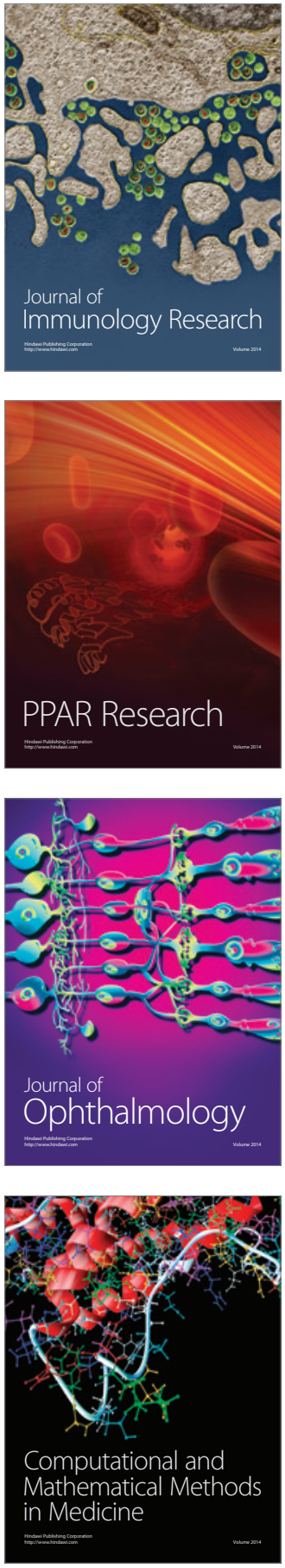



Gastroenterology

Research and Practice


\section{Hindawi}

Submit your manuscripts at

http://www.hindawi.com
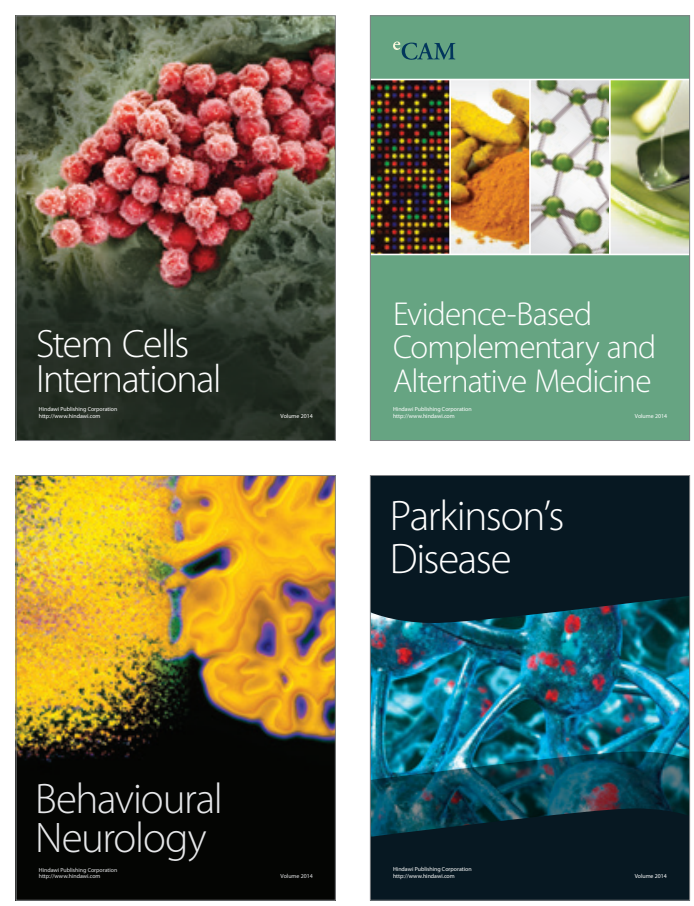

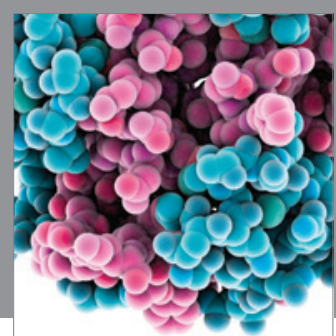

Journal of
Diabetes Research

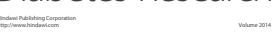

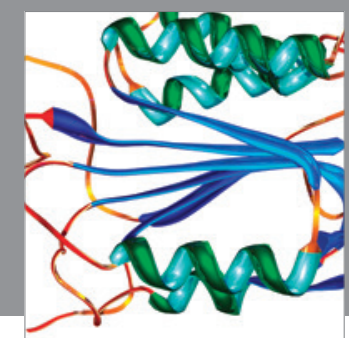

Disease Markers
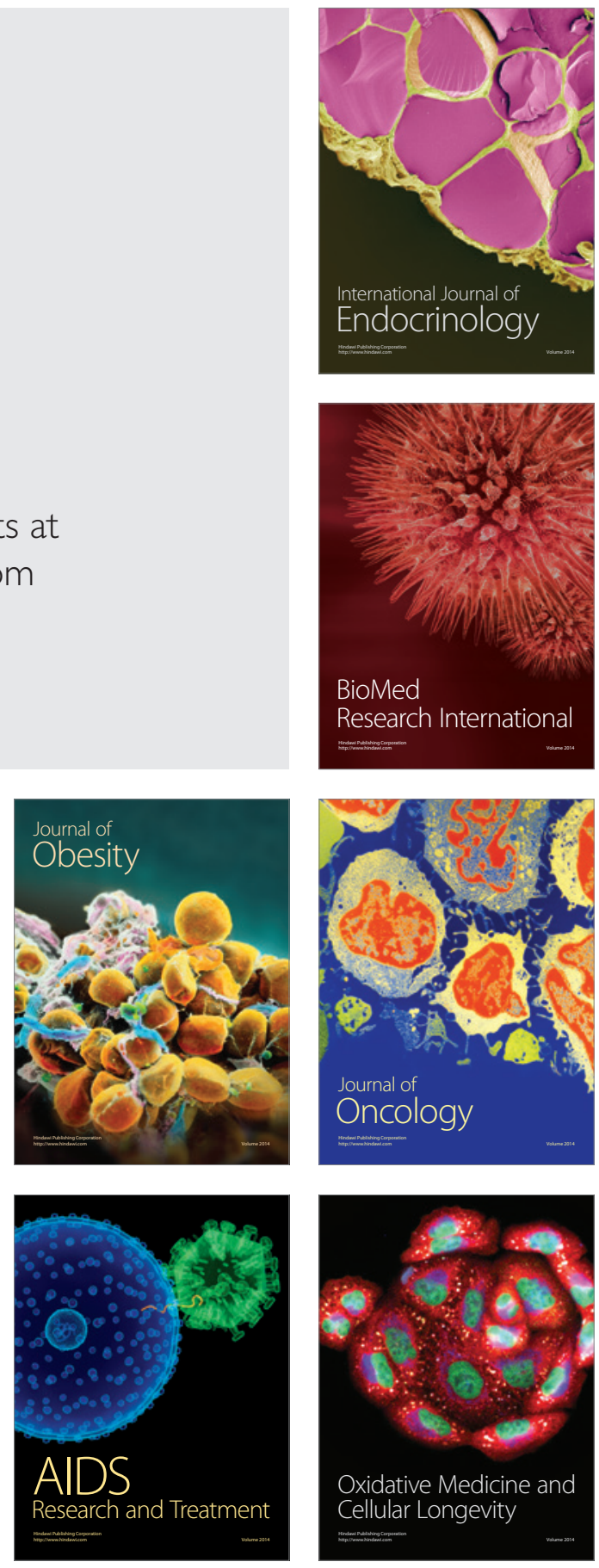